\title{
Sediment DIN fluxes and preferential recycling of benthic microalgal nitrogen in a shallow macrotidal estuary
}

\author{
Craig Tobias ${ }^{1,2, *}$, Anne Giblin ${ }^{1}$, James McClelland ${ }^{1}$, Jane Tucker $^{1}$, Bruce Peterson ${ }^{1}$ \\ ${ }^{1}$ The Ecosystems Center, Marine Biological Laboratory, Woods Hole, Massachusetts 02543, USA \\ ${ }^{2}$ Present address: US Geological Survey, 431 National Center, 12201 Sunrise Valley Drive, Reston, Virginia 20192, USA
}

\begin{abstract}
Sediment-water fluxes of $\mathrm{NH}_{4}{ }^{+}, \mathrm{NO}_{3}{ }^{-}$, dissolved inorganic carbon, and $\mathrm{O}_{2}$ were measured in cores collected from the upper Rowley River estuary, Massachusetts, and used to calculate rates of organic nitrogen $(\mathrm{N})$ mineralization, nitrification, and coupled and direct denitrification (DNF). The cores contained ${ }^{15} \mathrm{~N}$ label in benthic microalgae (BMA) and in $\mathrm{NO}_{3}{ }^{-}$in the overlying water as a result of an ongoing whole-estuary ${ }^{15} \mathrm{NO}_{3}{ }^{-}$enrichment study (NISOTREX II). The tracer allowed for estimation of gross $\mathrm{NO}_{3}{ }^{-}$regeneration in sediments and the contribution of BMA derived $\mathrm{N}$ to total mineralization. The mean mineralization rate between sites was $16.0 \pm 2.0 \mathrm{mmol} \mathrm{N} \mathrm{m}^{-2} \mathrm{~d}^{-1}$. Approximately 13 to $56 \%$ of the mineralized $\mathrm{N}$ was nitrified at rates ranging from 1.8 to $10.1 \mathrm{mmol} \mathrm{N} \mathrm{m}^{-2} \mathrm{~d}^{-1}$. Total denitrification was dominated by direct DNF $\left(3.6 \mathrm{mmol} \mathrm{N} \mathrm{m}{ }^{-2} \mathrm{~d}^{-1}\right)$ furthest upstream, where $\mathrm{NO}_{3}{ }^{-}$concentrations were highest. Coupled DNF was most important $\left(8.0 \mathrm{mmol} \mathrm{N} \mathrm{m}^{-2} \mathrm{~d}^{-1}\right)$ in the sediments with high nitrification and low water column $\mathrm{NO}_{3}^{-}$. A gross $\mathrm{NO}_{3}^{-}$flux from sediments to water of 0.9 to $2.1 \mathrm{mmol} \mathrm{N} \mathrm{m}^{-2} \mathrm{~d}^{-1}$ was estimated from the isotope dilution of $\delta^{15} \mathrm{NO}_{3}{ }^{-}$in the overlying water of the cores. The isotope dilution seen in the cores was also detected as a deviation from conservative $\delta^{15} \mathrm{NO}_{3}{ }^{-}$mixing along estuarine transects. Incorporation of this $\mathrm{NO}_{3}{ }^{-}$regeneration into the DNF calculations effectively increased the estimate of direct DNF by up to $50 \%$ and decreased the coupled DNF estimate by up to $220 \%$. Increasing $\delta^{15} \mathrm{NH}_{4}{ }^{+}$in the water of the cores indicated that the ${ }^{15} \mathrm{~N}$-labelled BMA were preferentially mineralized over bulk sediment organic $\mathrm{N}$. Additional ${ }^{15} \mathrm{~N}$ enrichments in the sediment bacterial biomarker diaminopimelic acid showed a link among ${ }^{15} \mathrm{~N}$-labeled BMA, active bacteria, and ${ }^{15} \mathrm{NH}_{4}{ }^{+}$released to the overlying water. Based on $\delta^{15} \mathrm{NH}_{4}{ }^{+}$enrichments in the cores, BMA accounted for approximately 50 to $100 \%$ of the $\mathrm{N}$ mineralized. An isotopic enrichment of $\delta^{15} \mathrm{NH}_{4}{ }^{+}$above background in the estuary was observed at a magnitude consistent with the core-based rates of BMA mineralization. These results provide further evidence that BMA are not unidirectional sinks for water column-dissolved organic nitrogen, but instead act to turn over $\mathrm{N}$ between sediments and estuarine water on the scale of days.
\end{abstract}

KEY WORDS: Nitrogen - Benthic microalgae $\cdot$ Microphytobenthos $\cdot$ Stable isotopes $\cdot$ Biomarkers · Nutrient flux · Denitrification

Resale or republication not permitted without written consent of the publisher

\section{INTRODUCTION}

Sediments are the dominant sites of nitrogen $(\mathrm{N})$ cycling within estuaries, and act as a source and/or sink for $\mathrm{N}$ in the overlying water column (Hopkinson et al. 1999, Twilley et al. 1999). Sediment denitrification (direct and coupled to organic matter mineralization) is the dominant mechanism of $\mathrm{N}$ attenuation in estuaries (Seitzinger 1988, Nixon et al. 1996, Cornwell et al. 1999), and benthic regeneration is an important source of dissolved inorganic $\mathrm{N}$ (DIN) supporting primary production in overlying waters (Kemp \& Boynton 1984, Holmes et al. 2000). Ultimately no understanding of estuarine $\mathrm{N}$ dynamics can be complete without quantification of $\mathrm{N}$ fluxes between the water column and sediments, and/or a contemporaneous accounting of the major $\mathrm{N}$ cycling processes generating those fluxes.

The principal $\mathrm{N}$ cycling reaction in estuarine sediments rich in organic matter is the mineralization of organic matter into ammonium. While organic-rich sed- 
iments tend to be a net source of $\mathrm{NH}_{4}{ }^{+}$, this flux may not represent all of the organic nitrogen oxidized during mineralization. Nitrification of $\mathrm{NH}_{4}^{+}$results in the production of $\mathrm{NO}_{3}^{-}$that in turn becomes available for flux to the water column or (coupled) denitrification (Blackburn \& Henriksen 1983, Seitzinger \& Giblin 1996). Sediment may also be a net sink for $\mathrm{NO}_{3}^{-}$in the overlying water through direct denitrification when water column $\mathrm{NO}_{3}^{-}$concentrations are high. Although the interaction between $\mathrm{N}$ cycling reactions can be complex, the overall balance between reactions that attenuate $\mathrm{N}$ flux from sediments and the water column (e.g. denitrification) and reactions that generate sediment DIN (e.g. mineralization and nitrification) regulates the impact of the benthos on the $\mathrm{N}$ status of the overlying water.

Benthic microalgae (BMA) in some estuaries play an instrumental role in attenuating the extent of sediment N flux to the overlying water (Sundbäck \& Miles 2000). Benthic microalgal photosynthesis accelerates the rate of coupled nitrification/denitrification (Risgaard-Petersen et al. 1994, An \& Joye 2001). BMA assimilation of porewater DIN and direct uptake of water column DIN lowers the total amount of $\mathrm{N}$ export from the estuary (Cerco \& Seitzinger 1997, Cabrita \& Brotas 2000, Sundbäck \& Miles 2000, Sundbäck et al. 2000, Tobias et al. 2003). However, despite the assumed role of BMA as a DIN sink, BMA stock size, turnover rate, and lability suggest that these organisms may also be important sources of organic matter fueling mineralization and subsequent DIN release. Some studies have examined the decomposition and fate of phytodetritus (Sun et al. 1993, Poremba 1994, Trimmer et al. 1999) and sediment diatoms (Middelburg et al. 2000), but have been limited solely to carbon. Despite the extensive distributions of benthic microalgal communities in many coastal environments, and their potential impact on estuarine $\mathrm{N}$ loads, the degree to which benthic microalgal $\mathrm{N}$ is preferentially mineralized and released is largely unexplored.

The extensive use of sediment/water flux incubations has proven useful for measuring the net uptake and release of various $\mathrm{N}$ fractions in multiple marine and estuarine environments (Boynton \& Kemp 1985, Hopkinson et al. 1999). However, an understanding of $\mathrm{N}$ dynamics based solely on $\mathrm{N}$ concentration changes in core incubations provides limited insight into underlying reactions, gross $\mathrm{N}$ transformation rates, or the identification of the $\mathrm{N}$ sources being processed and released. The incorporation of ${ }^{15} \mathrm{~N}$ labeling into specific $\mathrm{N}$ pools within flux incubations removes some of these limitations. ${ }^{15} \mathrm{~N}$ tracer studies have been widely used to examine water column and sediment $\mathrm{N}$ cycling (Blackburn \& Henriksen 1983, Nielsen 1992, Glibert \& Capone 1993, Bronk et al. 1994), but the technique has been underutilized as a means of estimating gross $\mathrm{N}$ regeneration or identifying the source of organic $\mathrm{N}$ fueling mineralization.

Here, we present an investigation of sediment DIN recycling in the Rowley River estuary. This work was conducted as part of the Nitrogen ISOTope Tracer EXperiment II (NISOTREX II project), which used a whole-estuary ${ }^{15} \mathrm{NO}_{3}^{-}$tracer addition to quantify the fate and transport of watershed derived $\mathrm{N}$ through the Rowley River estuary, Massachusetts (Tobias et al. 2003). To assess sediment DIN recycling we used a combination of sediment core flux incubations, estuarine dissolved inorganic ${ }^{15} \mathrm{~N}$ transects, and benthic microalgal and sediment bacterial biomarker ${ }^{15} \mathrm{~N}$ measurements. This approach took advantage of the existing ${ }^{15} \mathrm{~N}$ enrichments in the $\mathrm{NO}_{3}^{-}$and the benthic microalgal pools that resulted from the whole-estuary ${ }^{15} \mathrm{~N}$ addition. The ${ }^{15} \mathrm{~N}$ enrichments provided the unique opportunity to quantify gross $\mathrm{NO}_{3}^{-}$recycling by sediments and to estimate the relative importance of benthic microalgae to the total organic $\mathrm{N}$ mineralization.

\section{MATERIALS AND METHODS}

Site description. The Rowley River is a marshdominated estuary located in NE Massachusetts $\left(42^{\circ} 44^{\prime} \mathrm{N}, 70^{\circ} 52^{\prime} \mathrm{W}\right)$ within the Plum Island Ecosystem Long Term Ecological Research site (PIE-LTER). The $9 \mathrm{~km}$ long estuary drains an approximately $17.2 \mathrm{~km}^{2}$ mixed residential and forested watershed. Mean tidal amplitude and tidal excursion are $3 \mathrm{~m}$ and 3 to $6 \mathrm{~km}$, respectively. The estuary discharges to the Plum Island Sound, which in turn exchanges almost completely with the Gulf of Maine twice per day (Vallino \& Hopkinson 1998).

The study area consisted of 2 regions of mudflat located in the upper $1 \mathrm{~km}$ of the estuary approximately 13.5 and $14 \mathrm{~km}$ (hereafter referred to as $13.5 \mathrm{k}$ and $14 \mathrm{k}$ ) upstream from the Gulf of Maine (Fig. 1). Sampling was conducted during a period of relatively high river discharge, and the high tide salinities for $13.5 \mathrm{k}$ and $14 \mathrm{k}$ during the experiment were 9 and 3 ppt, respectively. Mudflat sediments were exposed at low tide and were heavily populated with benthic microalgae (pennate diatoms: Navicula spp., Nitzschia spp.).

The mudflats and overlying estuarine water were exposed to the high ${ }^{15} \mathrm{NO}_{3}^{-}$enrichments during, and for 3 wk prior to, this investigation as part of NISOTREX II. The estuarine isotope addition consisted of enriching the upper $4 \mathrm{~km}$ of the Rowley River with ${ }^{15} \mathrm{NO}_{3}{ }^{-}$added to the system from 11 July 2000 to 2 August 2000. The NISOTREX II ${ }^{15} \mathrm{NO}_{3}^{-}$isotope addition site was located at $\mathrm{Stn} 12.5 \mathrm{k}$, approximately $2.5 \mathrm{~km}$ downstream from the site of non-tidal freshwater input (15k). The enrichment solution added to the estuary was composed of 


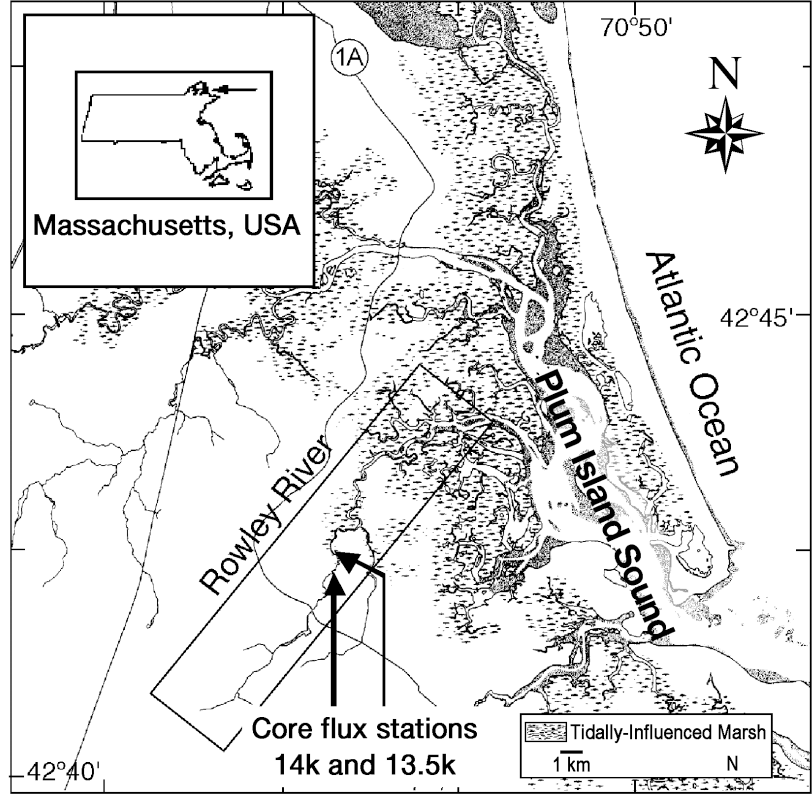

Fig. 1. Site location map

rhodamine wt (conservative tracer) and $\mathrm{K}^{15} \mathrm{NO}_{3}(0.9 \mathrm{M}$, 10 at $\%$ enriched). The solution was dripped continuously into the water column using a metering pump at a rate of $20 \mathrm{~g}{ }^{15} \mathrm{~N}$ per day. This rate of ${ }^{15} \mathrm{~N}$ addition enriched the water column $\delta^{15} \mathrm{NO}_{3}^{-}$by up to $1000 \%$ and the BMA by up to $100 \%$ over the course of the NISOTREX II project (Tobias et al. 2003).

Flux studies. The flux studies were conducted in order to quantify the net and gross exchange of DIN between sediments and the water column by estimating the exchange of total DIN and ${ }^{15} \mathrm{~N}-\mathrm{DIN}$, respectively. The protocol for the flux incubations was adapted from Giblin et al. (1997) and Hopkinson et al. (1999). Six $15 \mathrm{~cm}$ diameter $\times 30 \mathrm{~cm}$ deep sediment cores and $40 \mathrm{l}$ of overlying estuarine water were collected on 1 August 2000 from each of 2 stations (13.5k and $14 \mathrm{k}$ ) in the Rowley River. Water temperature and salinity were determined in the field, and the water was filtered $(<1.0 \mu \mathrm{m}$ cartridge filter) into carboys for transport (accompanied by the sediment cores) back to the laboratory. Upon arrival at the Woods Hole MBL facilities, the cores from each station were uncapped and held in the dark for at least $24 \mathrm{~h}$ within $\pm 2^{\circ} \mathrm{C}$ of the in situ station temperature from which they were collected. This holding period allowed for depletion of benthic microalgal energy reserves so that the observed fluxes during the incubations represented sediment processes independent of 'luxury' benthic microalgal $\mathrm{NO}_{3}^{-}$uptake. During 2 previous experiments using BMA from the Rowley River, we found no $\mathrm{NO}_{3}^{-}$ uptake by dense BMA resuspensions $\left(10^{6}\right.$ cells ml $\left.{ }^{-1}\right)$ in the dark following a $24 \mathrm{~h}$ dark holding period (C. Tobias unpubl. data). Just prior to initiating the flux measurements, $\sim 5 \mathrm{l}$ of filtered water $(<1.0 \mu \mathrm{m})$ collected from each station was added to its respective sediment core. All cores ( $\mathrm{n}=3$ cores site $^{-1}$ ) were capped and mixed with a magnetic stirrer during the incubations, and the flux incubations were performed in the dark at in situ temperatures $\left(16 \pm 2^{\circ} \mathrm{C}\right)$. The overlying water from all cores was sampled during the incubations and analyzed for the following parameters: dissolved oxygen (DO), $\mathrm{NH}_{4}^{+}, \mathrm{NO}_{3}^{-}+\mathrm{NO}_{2}^{-}$, and dissolved inorganic carbon (DIC). Isotopic enrichments of DIN $\left(\delta^{15} \mathrm{NH}_{4}^{+}\right.$and $\left.\delta^{15} \mathrm{NO}_{3}^{-}\right)$were determined in the overlying water at the start and end of the incubation period. The duration of the incubation was determined by the time required for the $\mathrm{O}_{2}$ concentration to drop by at least $2 \mathrm{ppm}$, but not by more than $3 \mathrm{ppm}$, to avoid having low DO concentrations as a factor affecting nitrification. The analytical methods used to determine the measured parameters are detailed in Table 1. In addition to the core fluxes, two $300 \mathrm{ml}$ BOD bottles of filtered water from each station were incubated in parallel with the cores to correct for water column respiration and $\mathrm{N}$ regeneration.

Net fluxes of $\mathrm{NH}_{4}^{+}, \mathrm{NO}_{3}^{-}, \mathrm{DIC}$, and $\mathrm{O}_{2}$ were estimated from the slope of linear regression of the change in the mass $\left(\mathrm{N}, \mathrm{C}\right.$, or $\left.\mathrm{O}_{2}\right)$ of the measured parameter versus incubation time in each core. These rates were normalized to core area to yield the flux estimate and reported as the mean and standard error of all cores.

Calculation of $\mathbf{N}$ cycling rates. Net fluxes of $\mathrm{NO}_{3}^{-}$ and $\mathrm{NH}_{4}^{+}$, mineralization, nitrification, coupled and direct denitrification (DNF), and gross $\mathrm{NO}_{3}^{-}$efflux from sediments were estimated from the DIN concentration and/or $\delta^{15} \mathrm{~N}$-DIN isotope data according to Table 2 . The calculation of all $\mathrm{N}$ cycling rates assumed that the sediment DIN pool $\left(\mathrm{NH}_{4}{ }^{+}\right.$and $\left.\mathrm{NO}_{3}{ }^{-}\right)$was in steady state.

Estuarine DIN and $\delta^{15} \mathbf{N}$-DIN transects. Water column sampling along the estuarine salinity gradient for $\mathrm{NH}_{4}^{+}, \mathrm{NO}_{3}^{-}, \delta^{15} \mathrm{NH}_{4}^{+}$and $\delta^{15} \mathrm{NO}_{3}^{-}$was conducted in the Rowley River estuary concurrent with the NISOTREX II ${ }^{15} \mathrm{~N}$ isotope addition experiment. Conservative mixing curves for $\mathrm{NO}_{3}^{-}$and $\delta^{15} \mathrm{NO}_{3}^{-}$were constructed for the estuary. Two-end member conservative mixing of fresh and salt water sources was used to predict $\mathrm{NO}_{3}^{-}$concentrations at any location (i) in the estuary according to:

$$
\mathrm{NO}_{3 \text { pred,i }}^{-}=f_{\text {salt }} \mathrm{NO}_{3, \text { salt }}^{-}+\left(1-f_{\text {salt }}\right) \cdot \mathrm{NO}_{3, \text { fresh }}^{-}
$$

where $\mathrm{NO}_{3,}{ }^{-}$salt and $\mathrm{NO}_{3,}$, fresh are the $\mathrm{NO}_{3}^{-}$concentrations in Plum Island Sound and the fresh river input, respectively, and $f_{\text {salt }}$ is the relative contribution of the saltwater-end member to the measured specific conductivity at Stn $i$ (i.e. the ratio of station conductivity to Plum Island Sound conductivity). 
Table 1. Summary of analytical methods (DIC: dissolved inorganic carbon; NA: not applicable)

\begin{tabular}{|c|c|c|c|c|c|c|c|}
\hline Parameter & Method & Units & Source & $\begin{array}{l}\text { Sample } \\
\text { frequency }\end{array}$ & $\begin{array}{l}\text { Sample } \\
\text { handling }\end{array}$ & $\begin{array}{l}\text { Holding } \\
\text { time }\end{array}$ & $\begin{array}{c}\text { Sample } \\
\text { preservation }\end{array}$ \\
\hline $\mathrm{O}_{2}$ & Probe $^{a}$ & $\mu \mathrm{M}$ & Hale (1980) & $\geq 5$ per flux & Immediate reading & NA & NA \\
\hline DIC & $\begin{array}{l}\text { Coulometric } \\
\mathrm{CO}_{2} \text { analyzer }\end{array}$ & $\mu \mathrm{M}$ & $\begin{array}{c}\text { Dickson \& Goyet } \\
\text { (1994) }\end{array}$ & 2 (initial + final) & Glass BOD bottles & $<4 \mathrm{mo}$ & $\mathrm{HgCl}_{2}, 4^{\circ} \mathrm{C}$ \\
\hline $\mathrm{NH}_{4}^{+}$ & $\begin{array}{c}\text { Spectro- } \\
\text { photometric }\end{array}$ & $\mu \mathrm{M}$ & Solorzano (1969) & $\sim 5$ per flux & Fixed within $1 \mathrm{~h}$ & $24 \mathrm{~h}$ & Phenol \\
\hline $\mathrm{NO}_{2}^{-}+\mathrm{NO}_{3}^{-}$ & $\begin{array}{c}\text { Flow injection } \\
\text { analyzer }\end{array}$ & $\mu \mathrm{M}$ & Diamond (1994) & $\sim 5$ per flux & Polyethylene bottles & $<4 \mathrm{mo}$ & Frozen \\
\hline$\delta^{15} \mathrm{NH}_{4}^{+}$ & $\begin{array}{l}\text { Volatization/ } \\
\text { acid trap }\end{array}$ & $\%$ & Holmes et al. (1997) & Initial and final & GFF-filtered & $<6 \mathrm{mo}$ & Frozen \\
\hline$\delta^{15} \mathrm{NO}_{3}^{-}$ & $\begin{array}{c}\text { Devarda's re- } \\
\text { duction, acid trap }\end{array}$ & $\%$ & Sigman et al. (1997) & Initial and final & GFF-filtered & $<6 \mathrm{mo}$ & Frozen \\
\hline
\end{tabular}

Similarly, a 2-compartment isotope-mixing model predicted the $\delta^{15} \mathrm{NO}_{3}^{-}$based upon the dilution of ${ }^{15} \mathrm{NO}_{3}^{-}$ released during NISOTREX II with ambient unlabelled $\mathrm{NO}_{3}^{-}$in the estuary. The predicted conservatively mixed $\delta^{15} \mathrm{NO}_{3}^{-}$was calculated from:

$\delta^{15} \mathrm{NO}_{3 \text { pred }, i}^{-}=1000\left[273 \cdot\left(\frac{{ }^{15} \mathrm{NO}_{3, \text { released }}^{-}+{ }^{15} \mathrm{NO}_{3, \text { estuary }}^{-}}{{ }^{14} \mathrm{NO}_{3, \text { released }}^{-}+{ }^{14} \mathrm{NO}_{3, \text { estuary }}^{-}}\right)-1\right]$

where ${ }^{15} \mathrm{NO}_{3, \text {,released }}^{-}$and ${ }^{14} \mathrm{NO}_{3, \text { released were the }}^{-}{ }^{15} \mathrm{~N}$ and ${ }^{14} \mathrm{~N}$ content of the ${ }^{15} \mathrm{NO}_{3}^{-}$added during NISOTREX II, ${ }^{15} \mathrm{NO}_{3}^{-}$, estuary and ${ }^{14} \mathrm{NO}_{3}^{-}$, estuary were the ${ }^{15} \mathrm{~N}$ and ${ }^{14} \mathrm{~N}$ content of the ambient estuarine $\mathrm{NO}_{3}^{-}$prior to the isotope addition. The ${ }^{15} \mathrm{~N}$ and ${ }^{14} \mathrm{~N}$ content of either $\mathrm{NO}_{3}^{-}$ source was calculated from the isotopic enrichment of the $\mathrm{NO}_{3}^{-}$sources $\left({ }^{15} \mathrm{NO}_{3}^{-}\right.$, released $=10$ at $\%$ excess ${ }^{15} \mathrm{~N}$; $\delta^{15} \mathrm{NO}_{3}^{-}$,estuary $=5 \%$ or $\sim 0.001$ at $\%$ excess) and the total $\mathrm{N}$ mass of each source. The mass of $\mathrm{N}-\mathrm{NO}_{3}^{-}$released into the Rowley assumed $1 \mathrm{l}$ of ${ }^{15} \mathrm{~N}$ addition solution (992 mM), and $\mathrm{NO}_{3}^{-}$,estuary was the mass of ambient $\mathrm{NO}_{3}^{-}$ diluting each liter of the addition solution. The diluting mass of ambient estuary $\mathrm{NO}_{3}^{-}$was calculated from the observed dilution of rhodamine wt (released with the ${ }^{15} \mathrm{~N}$ solution) and $\mathrm{NO}_{3}^{-}$concentration at each station.

BMA and bacterial biomarker analysis - diaminopimelic acid. Mudflat sediments were collected for the isolation and isotopic analysis of the bacterial specific $\mathrm{N}$-biomarker diaminopimelic acid (DAP). The $\delta^{15} \mathrm{~N}$ enrichment in DAP extracted from sediments was measured in order to examine the bacterial link between the highly enriched benthic microalgae (60 to $100 \%$ ) and any ${ }^{15} \mathrm{~N}$ tracer released from the sediments as DIN during the flux incubations.

The $\delta^{15} \mathrm{~N}$ of BMA was determined using EA-IRMS on cells collected directly from the mudflats at Stns $13.5 \mathrm{k}$ and $14 \mathrm{k}$ during NISOTREX II. On a falling tide, $210 \mu \mathrm{m}$
Nitex screen was placed on the exposed mudflat. The vertically migrating BMA encrusted the screen within 10 to $15 \mathrm{~min}$, and the screens were collected and rinsed with filtered seawater. The rinsate was trapped on a $50 \mu \mathrm{m}$ mesh sieve, underwent several water rinses, was filtered onto ashed GFF filters, and was dried at $40^{\circ} \mathrm{C}$ for IRMS analysis. Splits of the post $50 \mu \mathrm{m}$-sieved BMA were periodically examined under a microscope and checked for the presence of non-diatom detritus. Typically, the BMA 'isolates' samples were 85 to $95 \%$ BMA cells (i.e. 5 to $15 \%$ detrital contamination). Samples that were not at this purity level were rejected.

For DAP analysis, sediments (0 to $1 \mathrm{~cm}$ deep) were collected at 3 stations in the upper estuary $(12,13$ and $14 \mathrm{~km}$ upstream from the Gulf of Maine) for the measurement of $\delta^{15} \mathrm{~N}$. Collections occurred prior to the NISOTREX II ${ }^{15} \mathrm{~N}$ addition in order to estimate background natural abundance isotope enrichment, and again in the middle of the isotope addition period (10 July 2000). Sediments were stored at $-80^{\circ} \mathrm{C}$ prior to DAP extraction.

For each preparation, $5 \mathrm{~g}$ of dried sediment was ground in a mortar and placed in a $250 \mathrm{ml}$ Pyrex bottle with a Teflon-lined cap. In these bottles, samples were sonicated with $100 \mathrm{ml}$ benzene/methanol (3:2) and washed with $50 \mathrm{ml}$ methanol followed by deionized water to remove soluble organic matter (Pelz et al. 1998). Residues were collected by filtration on $0.2 \mu \mathrm{m}$ filters between each step and after the last rinse. Final residues were dried at $60^{\circ} \mathrm{C}$ overnight and then tightly capped and hydrolyzed with ultra-pure $6 \mathrm{M} \mathrm{HCl}$ for $24 \mathrm{~h}$ at $110^{\circ} \mathrm{C}$. The hydrolysate was evaporated to dryness at $55^{\circ} \mathrm{C}$ under a stream of $\mathrm{N}_{2}$, and the residues were redissolved in $0.01 \mathrm{~N} \mathrm{HCl}$ along with $0.5 \mu \mathrm{mol}$ of internal standard ( $\alpha$-aminoadipic acid). This solution was purified by filtration (0.65 $\mu \mathrm{m}$ Durapore filter) fol- 


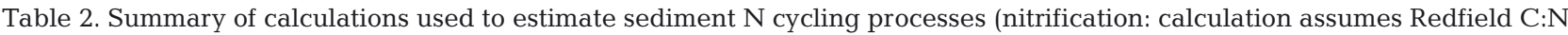
stoichiometry [C:N $=7$ ] of the respired organic matter; gross $\mathrm{NO}_{3}^{-}$regeneration: where $\mathrm{NO}_{3}^{-}$i,f and $\delta^{15} \mathrm{NO}_{3}^{-}$i,f are the nitrate concentration and ${ }^{15} \mathrm{~N}$ isotopic enrichment at the start [i] or end of the incubation $[f]$ ). The substitution of $\delta^{15} \mathrm{~N}$ values in place of atomic percent excess presented in Wessel \& Tietema (1992) is an approximation which introduced $<2 \%$ error into the calculation at $\delta^{15} \mathrm{~N}$ enrichments $<10000 \%$

\begin{tabular}{|c|c|c|}
\hline Process & Measurement & Source \\
\hline Mineralization & $\mathrm{NH}_{4}^{+}$flux + Nitrification & \multirow[b]{2}{*}{ Modified from Giblin et al. (1997) } \\
\hline $\begin{array}{l}\text { Nitrification from } \\
\text { DIC:DIN flux stoichiometry }\end{array}$ & $\frac{\text { DIC }-7\left(\mathrm{NH}_{4}^{+} \text {flux }+ \text { Gross } \mathrm{NO}_{3}^{-} \text {regeneration }\right)}{7}$ & \\
\hline $\begin{array}{l}\text { Gross } \mathrm{NO}_{3}^{-} \text {regeneration } \\
\text { (from }{ }^{15} \mathrm{~N} \text { isotope dilution) }\end{array}$ & Gross $\mathrm{NO}_{3}^{-}$regeneration $=\left[\frac{\left(\mathrm{NO}_{3, \mathrm{f}}^{-}-\mathrm{NO}_{3, i}^{-}\right)}{t}\right] \cdot \frac{\ln \left(\frac{\delta}{\delta}\right.}{\ln (}$ & $\begin{array}{l}\text { Modified from Wessel \& } \\
\text { Tietema (1992) }\end{array}$ \\
\hline $\begin{array}{l}\text { Direct denitrification } \\
\text { (direct DNF) }\end{array}$ & Net $\mathrm{NO}_{3}^{-}$flux + Gross $\mathrm{NO}_{3}^{-}$regeneration & \\
\hline $\begin{array}{l}\text { Coupled denitrification } \\
\text { (coupled DNF) }\end{array}$ & Nitrification - Gross $\mathrm{NO}_{3}^{-}$regeneration & \\
\hline
\end{tabular}

lowed by cation exchange chromatography (Dowex 50WX8-400 ion exchange resin). Amino acids were eluted with $2 \mathrm{M} \mathrm{NH}_{4} \mathrm{OH}$ and evaporated to dryness under a stream of $\mathrm{N}_{2}$ at $80^{\circ} \mathrm{C}$. Finally, the purified amino acids were derivatized to NPP-amino acid esters (Metges et al. 1996) and dried under a gentle stream of $\mathrm{N}_{2}$ at room temperature. Dried residues were dissolved in $75 \mu \mathrm{l}$ of ethyl acetate and stored in septum cap vials until analysis.

The stable isotopic compositions of nitrogen in NPP derivatives, $\alpha$-aminoadipic acid (internal standard), and DAP were analyzed by gas chromatography/combustion/isotope ratio mass spectrometer (GC/C/IRMS) using a Micromass Isoprime mass spectrometer interfaced to a Hewlett Packard 6890 gas chromatograph.

Mixes of amino acid derivatives from sediment samples were injected into the GC and separated on an HP-Ultra 2 column $(50 \mathrm{~m} \times 0.32 \mathrm{~mm}$ i.d., $0.5 \mu \mathrm{m}$ film thickness). GC conditions were such that individual amino acids eluted separately over the course of approximately $1.3 \mathrm{~h}$ (McClelland \& Montoya 2002). Amino acid derivatives that eluted prior to the internal standard were routed to the flame ionization detector of the gas chromatograph. From the internal standard onward, amino acid derivatives were routed to the mass spectrometer. Enroute to the mass spectrometer, the derivatives passed through an oxidation $\left(850^{\circ} \mathrm{C}\right)$ and a reduction furnace $\left(500^{\circ} \mathrm{C}\right)$, and a liquid nitrogen cold trap to remove water and $\mathrm{CO}_{2}$. Each sample run was preceded by 2 pulses of reference $\mathrm{N}_{2}$ and followed by 3 pulses of reference $\mathrm{N}_{2}$, the isotopic composition of which was calibrated against a variety of organic standards (peptone, histidine, and acetanilide) by continuous-flow isotope ratio mass spectrometry (CFIRMS) using a Carlo Erba NA 2100 elemental analyzer interfaced to a Micromass Optima mass spectrometer.

Standard mixtures of amino acids including DAP and internal standard were run through the entire analytical procedure to confirm the reproducibility of isotope measurements. Analytical error for the measurements was $\pm 0.5 \%$ o (standard error) for 3 injections.

\section{RESULTS}

\section{Fluxes and ${ }^{15} \mathrm{~N}$ dynamics}

At the start of the incubations, water from Stns $13.5 \mathrm{k}$ and $14 \mathrm{k}$ possessed similar $\mathrm{NH}_{4}^{+}$concentrations (6 to $8 \mu \mathrm{M})$, but differed in $\mathrm{NO}_{3}^{-}$concentrations by a factor of $3(14 \mathrm{k}=24 \mu \mathrm{M} ; 13.5 \mathrm{k}=7 \mu \mathrm{M})$. All sediment cores demonstrated net $\mathrm{NH}_{4}^{+}$production and net nitrate uptake (Fig. 2). The $\mathrm{NH}_{4}^{+}$flux from the sediment was greatest in cores collected furthest upstream (14k). Sediments from $\mathrm{Stn} 14 \mathrm{k}$ had a mean net $\mathrm{NH}_{4}^{+}$flux of $12.2 \mathrm{mmolN} \mathrm{m}^{-2} \mathrm{~d}^{-1}$, while $\mathrm{NH}_{4}^{+}$flux in the $13.5 \mathrm{k}$ cores averaged $7.9 \mathrm{mmolN} \mathrm{m}{ }^{-2} \mathrm{~d}^{-1}$ (Fig. 2). The mean $\mathrm{NH}_{4}^{+}$ flux from sediments to the water column for the upper $0.5 \mathrm{~km}$ reach of the Rowley estuary (i.e. the mean of Stns $13.5 \mathrm{k}$ and $14 \mathrm{k}$ ) was $10.1 \pm 2 \mathrm{mmolN} \mathrm{m}^{-2} \mathrm{~d}^{-1}$.

All cores lost approximately $20 \%$ of the initial $\mathrm{NO}_{3}^{-}$ concentration during the incubations. Total $\mathrm{NO}_{3}^{-}$loss was greater by a factor of 2 in cores from furthest upstream $(14 \mathrm{k})$, where the highest initial $\mathrm{NO}_{3}^{-}$concentration ( 23 to $24 \mu \mathrm{M}$ ) was encountered. The largest net $\mathrm{NO}_{3}^{-}$flux into the sediments $(14 \mathrm{k})$ was $2.6 \mathrm{mmolN} \mathrm{m}{ }^{-2}$ $\mathrm{d}^{-1}$, and the average net $\mathrm{NO}_{3}^{-}$flux in the $13.5 \mathrm{k}$ cores was $1.4 \mathrm{mmolN} \mathrm{m} \mathrm{m}^{-2}$ (Fig. 2). The mean net $\mathrm{NO}_{3}^{-}$ 


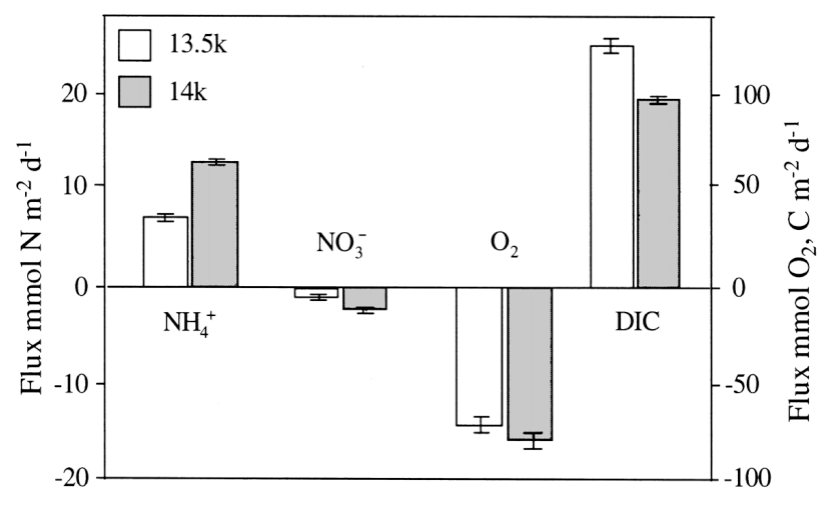

Fig. 2. Dissolved inorganic nitrogen $\left(\mathrm{NH}_{4}{ }^{+}, \mathrm{NO}_{3}^{-}\right), \mathrm{O}_{2}$, and dissolved inorganic carbon (DIC) flux summary. Positive values denote fluxes out of the sediments

flux for the upper $0.5 \mathrm{~km}$ reach of the Rowley estuary was $2.0 \pm 0.2 \mathrm{mmolN} \mathrm{m}^{-2} \mathrm{~d}^{-1}$.

Sediments from both stations were a net source of DIC and a net sink for $\mathrm{O}_{2}$. DIC production was highest in downstream cores $\left(13.5 \mathrm{k}_{;} 126 \mathrm{mmolC} \mathrm{m}^{-2} \mathrm{~d}^{-1}\right)$, and was approximately $30 \%$ higher than DIC production in sediments from $14 \mathrm{k}$ (Fig. 2). The DIC flux out of the sediments exceeded the $\mathrm{O}_{2}$ flux into the sediments at both stations and yielded mean respiratory quotients (RQs) of 1.8 for $13.5 \mathrm{k}$ and 1.2 for $14 \mathrm{k}$ sediments. DIC production in all cores exceeded the net flux of $\mathrm{NH}_{4}^{+}$at rates in excess of the 'Redfield' C:N ratio for phytoplankton $(\sim 7)$, for benthic microalgae at both stations, and in excess of the $\mathrm{C}: \mathrm{N}$ ratio of the bulk sediment measured at 13.5k (Table 3). The DIC: $\mathrm{NH}_{4}^{+}$flux ratios were 15.9 and 8.1 for $13.5 \mathrm{k}$ and $14 \mathrm{k}$ sediments, respectively.

The isotopic composition of the water column DIN pool with respect to both $\mathrm{NO}_{3}^{-}$and $\mathrm{NH}_{4}^{+}$changed during the flux incubations (Fig. 3). The $\delta^{15} \mathrm{NH}_{4}^{+}$increased from background natural abundance levels of (2.0 to $3.3 \%$ ) up to $22 \%$ in the $13.5 \mathrm{k}$ cores and $110 \%$ in the $14 \mathrm{k}$ cores. The largest $\delta^{15} \mathrm{NH}_{4}{ }^{+}$enrichment occurred at $14 \mathrm{k}$, where benthic microalgae and water column $\mathrm{NO}_{3}^{-}$ were more isotopically enriched than at $13.5 \mathrm{k}$ (Tobias et al. 2003; Fig. 3). As observed in the overlying water of the cores, the ${ }^{15} \mathrm{NH}_{4}^{+}$release from sediments may have generated a transient isotopic enrichment in estu-

Table 3. Bulk sediment percent organic matter, C:N, chlorophyll a (0 to $2 \mathrm{~cm}$ ), and benthic microalgal $\mathrm{C}: \mathrm{N}$. Percent organic matter determined by dry weight loss on ignition (LOI) $\left(500^{\circ} \mathrm{C}\right)$. Data are means $( \pm \mathrm{SE})$

\begin{tabular}{|c|c|c|c|c|}
\hline \multirow{2}{*}{$\begin{array}{l}\text { Station } \\
\text { (km upstream) }\end{array}$} & \multicolumn{3}{|c|}{$\longrightarrow$ Bulk sediment } & \multirow{2}{*}{$\begin{array}{l}\text { Benthic } \\
\text { microalgal } \\
\text { C:N }\end{array}$} \\
\hline & $\begin{array}{l}\text { Percent organic } \\
\text { matter (LOI) }\end{array}$ & $\mathrm{C}: \mathrm{N}$ & $\begin{array}{l}\text { Chlorophyll } a \\
\left(\mathrm{mg} \mathrm{chl} a \mathrm{~m}^{-3}\right)\end{array}$ & \\
\hline $13.5 \mathrm{k}$ & $7.2 \pm$ & $13.6 \pm 0.4$ & 131 & 7.1 \\
\hline $14 \mathrm{k}$ & $4.0 \pm 2.4$ & $13.5 \pm 0.2$ & $13847 \pm 3956$ & 7.7 \\
\hline
\end{tabular}
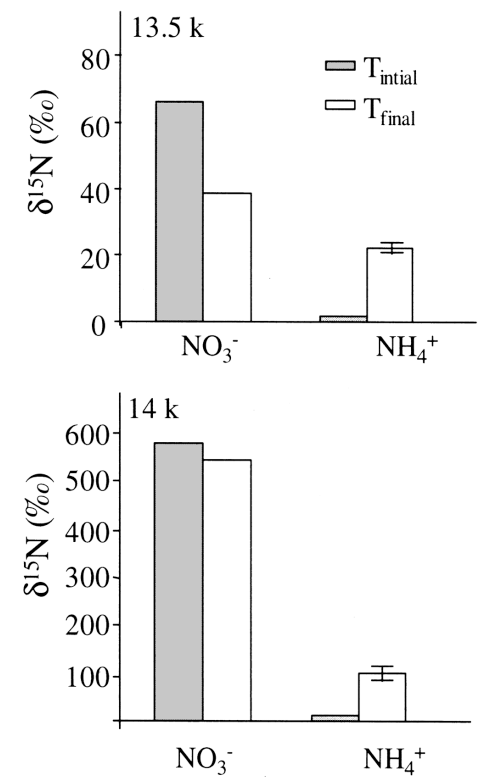

Fig. 3. Change in ${ }^{15} \mathrm{~N}$ isotopic enrichment of $\mathrm{NO}_{3}^{-}$and $\mathrm{NH}_{4}^{+}$in water overlying the core incubations

arine water column $\mathrm{NH}_{4}^{+}$during the 2nd week of the NISOTREX II tracer addition period (Fig. 4). Despite some uncertainty associated with $\delta^{15} \mathrm{NH}_{4}^{+}$analysis, background enrichment ranged from $5 \%$ at $11.5 \mathrm{k}$ to $12 \%$ at $14 \mathrm{k}$ and the $\mathrm{NH}_{4}^{+}$pool was clearly, but temporarily, enriched (above background) by up to $15 \%$ (Fig. 4) on the 10th day of the isotope addition period. The spatial pattern of $\delta^{15} \mathrm{NH}_{4}^{+}$enrichment above background measured on 20 July 2000 was coincident with a strong mid-estuary $\mathrm{NH}_{4}^{+}$maximum (Tobias et al. 2003), and the magnitude of the estuarine $\delta^{15} \mathrm{NH}_{4}{ }^{+}$was consistent with fluxes of ${ }^{15} \mathrm{~N}$-enriched $\mathrm{NH}_{4}^{+}$observed in sediment core incubations. When the ${ }^{15} \mathrm{NH}_{4}^{+}$flux observed in the cores was scaled to the estuarine residence time $(1.25 \mathrm{~d})$, areal extent of sediments, and water column $\mathrm{NH}_{4}^{+}$stock in the upper $2 \mathrm{~km}$ of the estuary, the predicted $11 \%$ enrichment in the estuarine ${ }^{15} \mathrm{NH}_{4}^{+}$pool is within the enrichment range observed in the estuary. The $\delta^{15} \mathrm{NH}_{4}^{+}$enrichment was not consistently observed during later sampling (e.g. 8 February 2000), when tidal volumes were larger and a midestuary $\mathrm{NH}_{4}^{+}$maximum was not detected (Tobias et al. 2003).

The $\delta^{15} \mathrm{NO}_{3}^{-}$in the overlying core water decreased during the incubation by $28 \%$ at $13.5 \mathrm{k}$ and $35 \%$ at $14 \mathrm{k}$ (Fig. 3). This observed isotopic dilution of the water column $\mathrm{NO}_{3}^{-}$equated with a gross $\mathrm{NO}_{3}^{-}$release from the sediments to the overlying water of 2.1 and $0.9 \mathrm{mmolN} \mathrm{m}^{-2} \mathrm{~d}^{-1}$ at Stns $13.5 \mathrm{k}$ and $14 \mathrm{k}$, respectively. The distribution of 


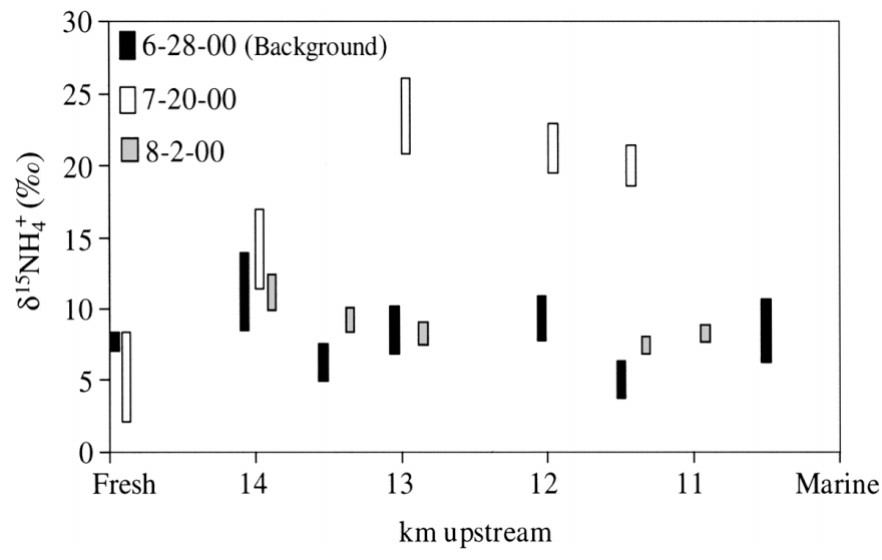

Fig. $4 .{ }^{15} \mathrm{~N}$ isotopic abundance of $\mathrm{NH}_{4}^{+}$in the Rowley River estuary prior to (i.e. background) and during (7-20-00; 8-2-00) the NISOTREX II ${ }^{15} \mathrm{NO}_{3}^{-}$isotope addition experiment. The 7-20-00 and 8-2-00 transects represent 10 and $21 \mathrm{~d}$ of estuarine isotope addition, respectively. Enrichment above background on 20 July 2000 coincided with a large mid-estuary ammonium maximum (Tobias et al. 2003). Dates: mm-dd-yy
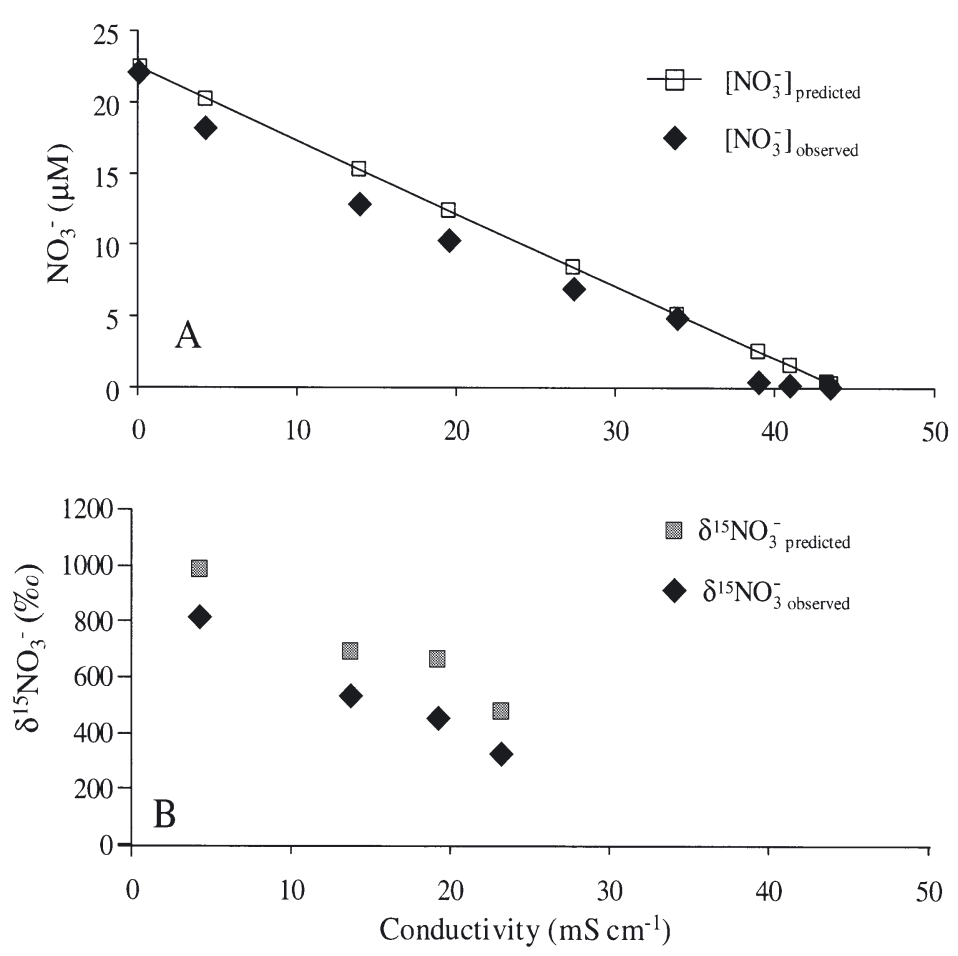

Fig. 5. Predicted and observed nitrate concentration (A) and ${ }^{15} \mathrm{~N}$ isotopic abundance (B) in the Rowley River estuary during the NISOTREX II ${ }^{15} \mathrm{NO}_{3}^{-}$isotope addition experiment. Predicted $\mathrm{NO}_{3}^{-}$concentrations were estimated from conservative mixing of the freshwater and marine water end members. Predicted $\delta^{15} \mathrm{NO}_{3}^{-}$values were estimated from dilution of the NISOTREX II ${ }^{15} \mathrm{NO}_{3}^{-}$addition solution with ambient estuarine nitrate using rhodamine wt as a conservative tracer $\delta^{15} \mathrm{NO}_{3}^{-}$and $\mathrm{NO}_{3}^{-}$along the axis of the estuary mimicked the pattern of gross nitrate release and net nitrate uptake observed in the cores (Fig. 5). Throughout the estuary, $\mathrm{NO}_{3}^{-}$concentrations were $\sim 3 \mu \mathrm{M}$ less than that predicted by the conservative mixing of the freshwater and marine water end members, indicating net $\mathrm{NO}_{3}^{-}$ uptake (Fig. 5). The $\delta^{15} \mathrm{NO}_{3}^{-}$values fell below the conservative isotope enrichment mixing line for the estuary by an average of $245 \%$ (or roughly 20 to $30 \%$ lower than expected), indicating an input of unlabeled $\mathrm{NO}_{3}^{-}$ (i.e. gross $\mathrm{NO}_{3}^{-}$regeneration from the sediments). Given the estimated gross $\mathrm{NO}_{3}^{-}$flux rate, the areal coverage of mudflat and channel sediments, estuarine residence time, $\mathrm{NO}_{3}^{-}$stock, and isotopic enrichment in the upper estuary, $\mathrm{NO}_{3}^{-}$regeneration would expectedly dilute the $\delta^{15} \mathrm{NO}_{3}^{-}$in the estuarine water column by $\sim 20 \%$. This dilution factor compares reasonably well to the observed deviation of $\delta^{15} \mathrm{NO}_{3}^{-}$from conservative mixing in the estuary.

\section{Calculation of multiple $\mathbf{N}$ processing rates}

Rates of gross mineralization, nitrification, and direct and coupled DNF in the sediments were calculated from the net $\mathrm{NH}_{4}^{+}, \mathrm{DIC}$, and $\mathrm{NO}_{3}^{-}$fluxes, and the $\delta^{15} \mathrm{NO}_{3}^{-}$data according to the equations in Table 2 (Fig. 6). The higher gross mineralization rate at $13.5 \mathrm{k}$ (18 mmol $\mathrm{N} \mathrm{m}^{-2} \mathrm{~d}^{-1}$ ) was not accompanied by a higher bulk sediment percent organic matter or lower $\mathrm{C}: \mathrm{N}$ ratio relative to $14 \mathrm{k}$ (Table 3 ). Approximately $80 \%$ of the $\mathrm{NH}_{4}^{+}$produced from gross mineralization at $14 \mathrm{k}$ $\left(14 \mathrm{mmolN} \mathrm{m}{ }^{-2} \mathrm{~d}^{-1}\right)$ was fluxed to the overlying water, while the majority $(60 \%)$ of the $\mathrm{NH}_{4}{ }^{+}$produced from mineralization at $13.5 \mathrm{k}$ was consumed by nitrification. Nitrification rates were 4 -fold higher at $13.5 \mathrm{k}$ and supported primarily the coupled denitrification rates, while the fate of $\mathrm{NO}_{3}^{-}$produced from nitrification in upstream (14k) sediments was evenly split between coupled DNF and gross $\mathrm{NO}_{3}^{-}$flux back to the water column (Fig. 6).

Total denitrification (direct DNF + coupled DNF) was greatest in $13.5 \mathrm{k}$ sediments, and was dominated nearly 3:1 by coupled DNF at a mean rate of $8.0 \mathrm{mmolN} \mathrm{m}^{-2} \mathrm{~d}^{-1}$. In contrast, the lower rates of total denitrification at (14k) were accompanied by a 4:1 dominance of direct DNF over coupled DNF. Despite the difference in the relative importance of direct and coupled DNF pathways, the direct DNF rates between stations were nearly identical (3.5 to $3.6 \mathrm{mmolN} \mathrm{m}^{-2} \mathrm{~d}^{-1}$; Fig. 6). The net $\mathrm{NO}_{3}^{-}$flux component of direct DNF (Table 2) was 2 -fold greater under the higher $\mathrm{NO}_{3}^{-}$concentrations at $14 \mathrm{k}$ (Fig. 2). In contrast, the bulk of direct DNF at $13.5 \mathrm{k}$ was comprised of $\mathrm{NO}_{3}^{-}$that had been regenerated and released to the water column prior to being denitrified. 

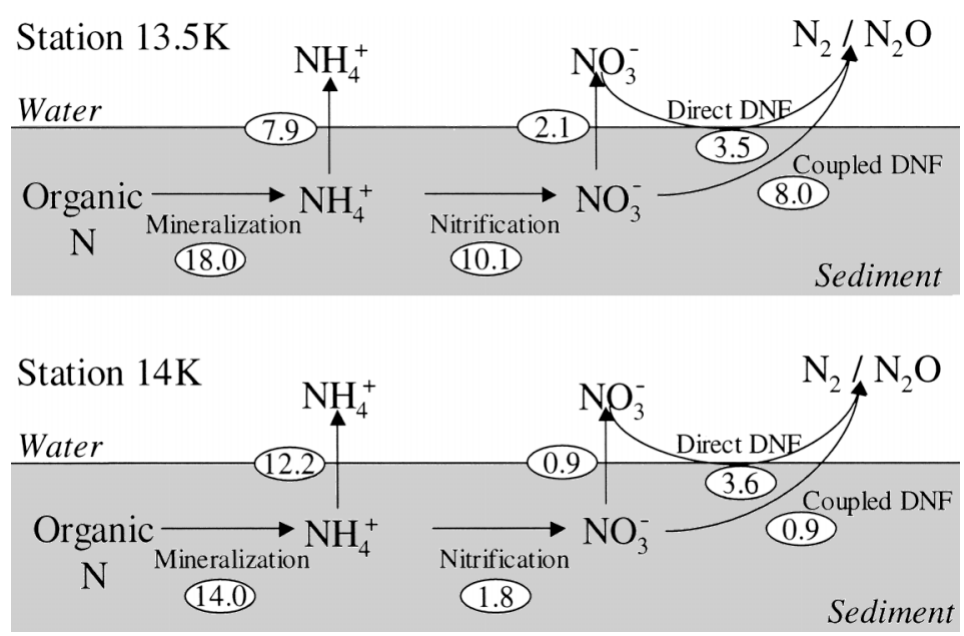

Fig. 6. Summary of $\mathrm{N}$ cycling rates $\left(\mathrm{mmol} \mathrm{N} \mathrm{m} \mathrm{m}^{-2} \mathrm{~d}^{-1}\right)$ derived from net dissolved inorganic nitrogen and dissolved inorganic carbon fluxes and $\delta^{15} \mathrm{~N}$-DIN data. Rates calculated according to equations presented in Table 2 (DNF: denitrification)

\section{Distribution of ${ }^{15} \mathrm{~N}$ tracer in benthic compartments}

Bulk sediments, BMA, and sediment bacteria all contained elevated amounts of ${ }^{15} \mathrm{~N}$ as a result of the 3 -wk ${ }^{15} \mathrm{~N}$ isotope addition during the NISOTREX II project. Isotopic enrichments of these benthic pools increased with distance upstream and paralleled the spatial $\delta^{15} \mathrm{NO}_{3}^{-}$distribution in the estuary (Tobias et al. 2003; Fig. 7). One week prior to when the flux cores were collected at $13.5 \mathrm{k}$ and $14 \mathrm{k}$, BMA was the most highly ${ }^{15} \mathrm{~N}$-enriched pool (83 to $97 \%$ ), followed by the sediment bacterial biomarker (DAP; 21 to $26 \%$ ), and bulk sediments ( 7 to $8 \%$ ). Along with the water column

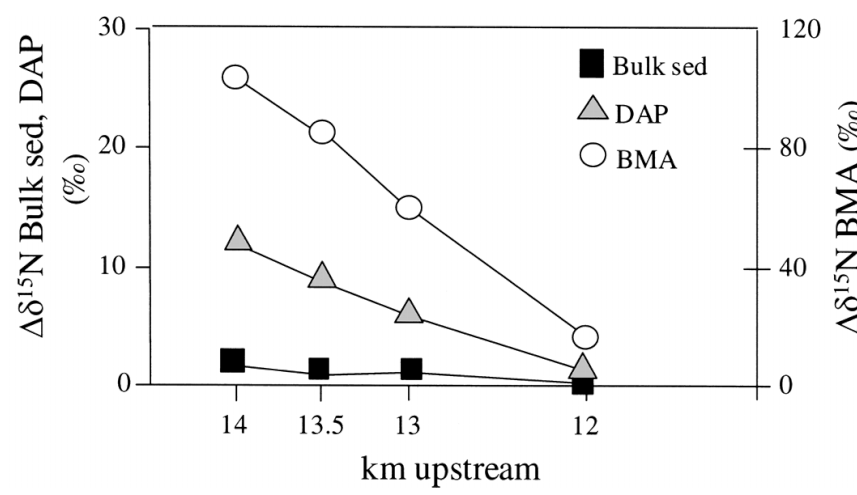

Fig. 7. Distribution of ${ }^{15} \mathrm{~N}$ isotopic enrichment in bulk sediments, sediment bacterial biomarker (DAP), and benthic microalgae (BMA) during NISOTREX II. Background $\delta^{15} \mathrm{~N}$ values (prior to the NISOTREX II ${ }^{15} \mathrm{NO}_{3}^{-}$addition) were as follows: bulk sediment $=4$ to $6 \%$; DAP $=5$ to $10 \%$; and $\mathrm{BMA}=1$ to $2 \%$ o
$\mathrm{NO}_{3}{ }^{-}$, these benthic pools represented potential sources of ${ }^{15} \mathrm{NH}_{4}^{+}$that were fluxed into the overlying water in the estuary (Fig. 7) and in the core incubations.

\section{DISCUSSION}

Studies that quantify net sediment-water nutrient exchanges have better defined the role of the estuarine benthos (Boynton \& Kemp 1985, Hopkinson et al. 1999). The incorporation of ${ }^{15} \mathrm{~N}$ tracer into these flux experiments provided 2 additional elements of information that would not have been available had these incubations lacked the tracer. First, the appearance of ${ }^{15} \mathrm{~N}$ in the $\mathrm{NH}_{4}^{+}$pool during the incubation provided the ability to identify that benthic microalgae were preferentially mineralized. Second, the isotopic dilution of water column $\mathrm{NO}_{3}^{-}$allowed for calculation of gross $\mathrm{NO}_{3}^{-}$ release from the sediments. Incorporating this gross $\mathrm{NO}_{3}^{-}$release into stoichiometry-based denitrification calculations led to an improved estimate of direct and coupled denitrification.

\section{Preferential mineralization of benthic microalgal $\mathbf{N}$}

Mineralization was the dominant process in the sediments. The daily $\mathrm{NH}_{4}^{+}$flux rates were near the upper end of the range reported for other estuaries (Caffrey 1995, Hopkinson et al. 1999, Warnken et al. 2000), and may represent generous daily estimates because the potential interaction between emersion period and illumination was not directly considered (Thornton et al. 1999). Regardless, the source of the $\mathrm{NH}_{4}^{+}$flux was isotopically enriched in ${ }^{15} \mathrm{~N}$. If the $\mathrm{NH}_{4}^{+}$flux was produced from the mineralization of bulk sediment organic matter $\left(\delta^{15} \mathrm{~N} \approx 7 \%\right.$ ), the $\delta^{15} \mathrm{NH}_{4}^{+}$in the overlying water column would have increased $<4 \%$ during the experiment. Instead, the substantial ${ }^{15} \mathrm{~N}$ enrichment (Fig. 3) of the $\mathrm{NH}_{4}^{+}$in the overlying water during all flux incubations indicated that a fraction of the bulk sediment (enriched in ${ }^{15} \mathrm{~N}$ ) was being preferentially mineralized. There were 2 sources of ${ }^{15} \mathrm{~N}$ within the estuary that possessed a sufficiently high enrichment to have potentially supported the observed ${ }^{15} \mathrm{NH}_{4}^{+}$ fluxes: $\mathrm{NO}_{3}^{-}$and BMA (Fig. 7).

The highly enriched ${ }^{15} \mathrm{NO}_{3}^{-}$pool could have been ammonified into ${ }^{15} \mathrm{NH}_{4}^{+}$. Dissimilatory nitrate reduction to ammonium (DNRA) can occur in anoxic sediments and porewaters (Koike \& Sørenson 1988, Tobias et al. 2001a,b). While there is a possibility that DNRA 
could have contributed to some of the ${ }^{15} \mathrm{NH}_{4}^{+}$flux at $14 \mathrm{k}$, in general the DNRA rates could not have produced enough ${ }^{15} \mathrm{NH}_{4}^{+}$to account for the increase of water column $\delta^{15} \mathrm{NH}_{4}^{+}$when we considered the total amount of $\mathrm{NH}_{4}^{+}$diffused from the sediment to the overlying water. If DNRA was assumed to be the only source of ${ }^{15} \mathrm{NH}_{4}{ }^{+}$at a generous production rate equal to $50 \%$ of the water column $\mathrm{NO}_{3}^{-}$loss rate (Herbert 1999, and others cited therein), the additional mass of unlabeled $\mathrm{NH}_{4}^{+}$produced from organic matter mineralization would have isotopically diluted the DNRAproduced ${ }^{15} \mathrm{NH}_{4}^{+}$to a $\delta^{15} \mathrm{~N}$ value far too low (by at least a factor of 5 at $13.5 \mathrm{k}$ and a factor 2 at $14 \mathrm{k}$ ) to have generated the observed enrichment in the water column $\delta^{15} \mathrm{NH}_{4}{ }^{+}$. If DNRA contributed at all to the ${ }^{15} \mathrm{NH}_{4}{ }^{+}$flux (unusual considering the low salinity of the stations), it could not have caused the changes in water column $\delta^{15} \mathrm{NH}_{4}^{+}$without another ${ }^{15} \mathrm{~N}$ source in the $\mathrm{NH}_{4}{ }^{+}$produced by mineralization. Likewise, assimilatory nitrate ammonification (i.e. bacterial $\mathrm{NO}_{3}^{-}$assimilation followed by $\mathrm{NH}_{4}^{+}$excretion) was not likely to be a significant mechanism of generating the ${ }^{15} \mathrm{NH}_{4}{ }^{+}$. Although this process has been reported in marine and estuarine environments, it was observed only when $\mathrm{NO}_{3}{ }^{-}$concentrations exceeded all other $\mathrm{N}$ sources by at least an order of magnitude (Kirchman \& Wheeler 1998, Middelburg \& Nieuwenhuize 2000). The final piece of evidence suggesting a minimal role for nitrate ammonification was that previous sediment incubations from an adjacent estuary in the Plum Island LTER (Parker River) containing high ${ }^{15} \mathrm{NO}_{3}^{-}$enrichments $(\sim 100000 \%)$ but lacking BMA enrichment yielded negligible increases in $\delta^{15} \mathrm{NH}_{4}^{+}$.

Although we cannot rule out $\mathrm{NO}_{3}^{-}$ammonification entirely, we suggest an explanation for the observed ${ }^{15} \mathrm{NH}_{4}^{+}$fluxes that is more consistent with the mineralization rates and fluxes of $\mathrm{NH}_{4}{ }^{+}$and ${ }^{15} \mathrm{NH}_{4}{ }^{+}$. The ${ }^{15} \mathrm{NH}_{4}{ }^{+}$ was produced from the preferential mineralization of the ${ }^{15} \mathrm{~N}$-enriched benthic microalgal biomass. Very high sediment chlorophyll in the upper $2 \mathrm{~cm}$ of sediment $\left(\sim 13 \mathrm{~g} \mathrm{chl} \mathrm{a} \mathrm{m}^{-3}\right)$ was measured at both stations. The BMA provided a low C:N source of isotopically enriched $\mathrm{N}$ that was likely more labile than bulk particulate organic matter, which included contributions from higher C:N terrestrial and/or macrophyte-derived sources (Hopkinson et al. 1999). Chlorophyll-derived N (assuming molar ratios of chl $a: \mathrm{C}=50$ and BMA C:N of 7.1 at $13.5 \mathrm{k}$ and 7.7 at $14 \mathrm{k}$ ) composed 3 to $4 \%$ of total sediment $\mathrm{N}$ in the top $2 \mathrm{~cm}$ but accounted for 50 to $75 \%$ of the ${ }^{15} \mathrm{~N}$ excess in the sediments (Tobias et al. 2003). This dichotomy indicated that BMA was a disproportionately active component of the bulk sediment.

Additional evidence supporting BMA as a source for mineralization was seen in the ${ }^{15} \mathrm{~N}$ of the sediment bacteria (as measured by DAP; Fig. 7). The $\delta^{15} \mathrm{~N}$ of bacterial
DAP in the upper $1 \mathrm{~cm}$ of sediment showed a marked enrichment over that of bulk sediment particulate organic nitrogen as well as enrichment above natural abundance background levels determined prior to whole-estuary isotope addition. The $\delta^{15} \mathrm{~N}$-DAP enrichment indicated bacterial utilization of recently degraded organic matter derived from a source that was enriched in ${ }^{15} \mathrm{~N}$. As such the elevated $\delta^{15} \mathrm{~N}$ DAP established a link among the ${ }^{15} \mathrm{~N}$-enriched BMA, actively mineralizing bacteria, and the ${ }^{15} \mathrm{NH}_{4}^{+}$flux from the sediments. While the possibility exists that DAP enrichment reflected some direct $\mathrm{NO}_{3}^{-}$assimilation, we believe that to be unlikely, given the strong preference of bacteria for reduced $\mathrm{N}$ sources which are abundantly available in these porewaters. Similarly high isotopic enrichments in sediment bacterial lipids have been observed following ${ }^{13} \mathrm{C}$ additions to BMA-dominated sediments (Middelburg et al. 2000). While the connection between BMA and sediment bacteria can represent a link for carbon to higher trophic levels (Middelburg et al. 2000), sediment bacteria in this study operated more as sink for BMA-derived $\mathrm{N}$ by mediating its mineralization and release back to the water column.

A simple 2-end member (BMA and water column $\mathrm{NH}_{4}^{+}$) isotope mixing calculation provided an estimate of the percent of the total $\mathrm{NH}_{4}{ }^{+}$flux derived from enriched BMA. Given estimates of BMA enrichments in the estuary ( $97 \%$ at $14 \mathrm{k}_{;} 83 \%$ at $\left.13.5 \mathrm{k}\right)$, the $\mathrm{NH}_{4}^{+}$ flux rate, and the observed $\delta^{15} \mathrm{NH}_{4}^{+}$change in the cores, mineralization of BMA could account for roughly 40 to $50 \%$ of the total $\mathrm{NH}_{4}{ }^{+}$flux at $13.5 \mathrm{k}$ and approximately $100 \%( \pm 5$ to $10 \%)$ of the $\mathrm{NH}_{4}^{+}$flux at $14 \mathrm{k}$. These estimates (particularly at $14 \mathrm{k}$ ) might be regarded as somewhat liberal for 2 reasons. First, our ${ }^{15} \mathrm{~N}$ enrichment estimate for BMA was very conservative due to variable detrital contamination (but typically $<5$ to $15 \%$ ) of the BMA isolates. An underestimate in the BMA enrichment would result in an apparent increase in the proportion that BMA-N contributed to total mineralization. Second, we do not completely exclude the possibility that direct $\mathrm{NO}_{3}^{-}$ammonification contributed to the ${ }^{15} \mathrm{NH}_{4}{ }^{+}$flux (at $14 \mathrm{k}$ only). However, microalgal ${ }^{13} \mathrm{C}$ enrichment studies (Middelburg et al. 2000) demonstrated that respiration of BMA-derived carbon accounted for up to $40 \%$ of the loss of ${ }^{13} \mathrm{C}$ tracer added to the microphytobenthos in the Scheldt estuary. The higher proportion of BMA mineralized in the more sandy sediments of the Rowley estuary at $14 \mathrm{k}$ was also noted in the ${ }^{13} \mathrm{C}$ tracer additions to high-sand sediments in the Scheldt.

Although we lacked porewater $\delta^{15} \mathrm{NH}_{4}^{+}$measurements, it is reasonable to suggest that the shallowest ( 0 to $2 \mathrm{~cm}$ ) BMA-dominated sediments possessed the highest $\delta^{15} \mathrm{NH}_{4}^{+}$values. The small amount of isotopic dilution of $\delta^{15} \mathrm{NH}_{4}^{+}$prior to its release to the overlying water indi- 
cated a disconnection between the BMA-dense shallow sediments $(0$ to $1 \mathrm{~cm})$ and the large porewater $\mathrm{NH}_{4}^{+}$ pool found in deeper sediments. The $\mathrm{NH}_{4}{ }^{+}, \mathrm{DAP}$, and BMA isotopic evidence suggested that the sedimentwater exchange of DIN was largely controlled by reactions occurring in the BMA layer, rather than by an integration of processes or porewater inventory existing across, a deeper sediment cross section. The ultimate source of the ${ }^{15} \mathrm{~N}$ in the Rowley BMA was water column ${ }^{15} \mathrm{NO}_{3}^{-}$assimilated prior to core collection for the flux experiments. Therefore, the importance of BMA in regulating sediment water $\mathrm{N}$ exchange in the Rowley included both roles as a DIN sink (Cerco \& Seitzinger 1997, Sundbäck \& Miles 2000) and in rapidly recycling DIN recently imported from the watershed.

\section{Nitrification, gross $\mathrm{NO}_{3}^{-}$flux, and denitrification}

The principal fate of $\mathrm{NH}_{4}{ }^{+}$produced during mineralization at $14 \mathrm{k}$ was diffusion to the overlying water, while the bulk of the $\mathrm{NH}_{4}^{+}$generated at $13.5 \mathrm{k}$ was nitrified (Fig. 6). Nitrification at $13.5 \mathrm{k}$ accounted for $>^{1 / 2}$ of the total organic $\mathrm{N}$ initially mineralized into $\mathrm{NH}_{4}^{+}$. At both stations, a portion of the $\mathrm{NO}_{3}^{-}$produced during nitrification was fluxed to the overlying water although the sediments acted as a net denitrifying $\mathrm{NO}_{3}^{-}$sink (Figs. 2, 3 \& 5). The gross $\mathrm{NO}_{3}^{-}$release was large enough to impact the $\delta^{15} \mathrm{NO}_{3}^{-}$values in the estuary (Fig. 5). Yet there was some uncertainty in the rate estimate because the exact $\delta^{15} \mathrm{NO}_{3}^{-}$of the $\mathrm{NO}_{3}^{-}$diffusing from the sediments could not be measured due to its low porewater stock size. The rate based on the isotope dilution equation (Table 2) yielded a conservative minimum $\mathrm{NO}_{3}^{-}$release estimate (Fig. 6). A maximum estimate was also calculated using an isotope dilution model that assumed the $\delta^{15} \mathrm{NO}_{3}^{-}$was equal to that of the diffusing $\delta^{15} \mathrm{NH}_{4}{ }^{+}$. Because gross $\mathrm{NO}_{3}^{-}$release was small relative to the other measured processes, applying the maximum rate estimates $\left(1.2 \mathrm{mmolN} \mathrm{m}^{-2} \mathrm{~d}^{-1}\right.$ at $14 \mathrm{k}$ and $4.2 \mathrm{mmolN} \mathrm{m}^{-2} \mathrm{~d}^{-1}$ at $13.5 \mathrm{k})$ would have only marginal impact on the overall interpretation of sediment $\mathrm{N}$ cycling. Despite the uncertainty, the identification of this gross $\mathrm{NO}_{3}^{-}$flux from the sediments demonstrated the rapid turnover (days) of $\mathrm{NO}_{3}^{-}$in the estuary, and allowed for a better partitioning of direct and coupled denitrification.

Nitrate in the Rowley River estuary was more dynamic than the conservative $\mathrm{NO}_{3}^{-}$mixing along the estuarine axis suggested (Fig. 5), and was analogous to 'nutrient spiraling' observed in streams where rapid turnover of $\mathrm{NO}_{3}^{-}$between water and sediments underlies the imprint of moderate net $\mathrm{NO}_{3}^{-}$loss during downstream transport (Peterson et al. 2001). Assuming the following: average gross $\mathrm{NO}_{3}^{-}$flux from the sediments $\left(2.0 \mathrm{mmol} \mathrm{m} \mathrm{m}^{-2} \mathrm{~d}^{-1}\right)$, the direct denitrification rate
(3.5 mmol m $\left.\mathrm{m}^{-2} \mathrm{~d}^{-1}\right)$, mean water depth $(1.5 \mathrm{~m})$, and the volume-weighted average $\mathrm{NO}_{3}^{-}$concentration in the estuarine water column, approximately $12 \%$ of the water column $\mathrm{NO}_{3}^{-}$stock in the upper estuary was turned over each day. At this turnover rate, sediment recycling of $\mathrm{NO}_{3}^{-}$becomes the dominant control on water column $\mathrm{NO}_{3}^{-}$dynamics in the upper estuary at hydraulic residence times in excess of $5 \mathrm{~d}$, and a residence time in excess of $12 \mathrm{~d}$ would be required to remove all water column $\mathrm{NO}_{3}^{-}$via direct denitrification. Despite the $\mathrm{NO}_{3}^{-}$turnover, riverine $\mathrm{NO}_{3}^{-}$loading was more important than $\mathrm{NO}_{3}^{-}$recycling. The hydraulic residence time for the upper estuary was $<2$ d during the study, and $\mathrm{NO}_{3}^{-}$regeneration was roughly 10 to $15 \%$ of the daily riverine $\mathrm{NO}_{3}^{-}$flux.

Nevertheless, the gross $\mathrm{NO}_{3}^{-}$flux was sufficiently high to isotopically dilute the $\delta^{15} \mathrm{NO}_{3}^{-}$measured in the estuary below enrichments predicted by conservative $\delta^{15} \mathrm{NO}_{3}^{-}$ mixing (Fig. 5). While non-conservative $\delta^{15} \mathrm{NO}_{3}^{-}$mixing (at natural abundance levels) has provided evidence of nitrification in other estuaries, these systems have also demonstrated significant subsidies of $\mathrm{NO}_{3}^{-}$(Middelburg $\&$ Nieuwenhuize 2001). In contrast we were able to detect $\mathrm{NO}_{3}^{-}$regeneration through $\delta^{15} \mathrm{NO}_{3}^{-}$depletion relative to conservative $\delta^{15} \mathrm{NO}_{3}^{-}$mixing in the Rowley with little deviation (slight net uptake) from conservative $\mathrm{NO}_{3}^{-}$mixing in the estuary. The predicted $\delta^{15} \mathrm{NO}_{3}^{-}$values in the estuary were based on the use of rhodamine wt as a conservative (water dilution) tracer. Because no corrections for potential rhodamine adsorption and/or photo-oxidation were applied to the rhodamine data (Vallino \& Hopkinson 1998), the resulting predicted $\delta^{15} \mathrm{NO}_{3}^{-}$values (and the implied deviation from conservative isotope mixing due to $\mathrm{NO}_{3}^{-}$regeneration) should be regarded as minimum estimates.

\section{Denitrification}

Direct denitrification rates were consistent with reported rates for other silty estuarine sediments under similar magnitudes of $\mathrm{NO}_{3}^{-}$supply (Seitzinger 1988, Dong et al. 2000, Sundbäck \& Miles 2000). After scaling rates to the upper $2 \mathrm{~km}$ of the estuary and correcting the mean denitrification rate for tidal inundation times, we estimated that direct denitrification in the upper $2 \mathrm{~km}$ of the estuary removed $0.67 \mathrm{~kg}$ of total $\mathrm{N}$ $\mathrm{d}^{-1}$ from the estuary $\left(\sim 11 \%\right.$ of the total daily $\mathrm{NO}_{3}^{-}$flux from the watershed). Nitrate removed via direct DNF alone was substantially higher than the fraction of total $\mathrm{N}$ denitrified in other estuaries as predicted by $\mathrm{N}$ loading, residence time, and mean water depth (Nixon et al. 1996). This disproportionately large amount of DNF in the Rowley River suggests that small, well-flushed estuaries may not adhere well to existing regression 
models that predict DNF from physical estuarine characteristics (Nixon et al. 1996).

As seen in other organic-rich sediments, direct denitrification dominated total denitrification when $\mathrm{NO}_{3}^{-}$ concentrations were high $(14 \mathrm{k})$, and coupled denitrification dominated at lower $\mathrm{NO}_{3}{ }^{-}$concentrations $(13.5 \mathrm{k}$; Weston et al. 1996). Coupled DNF in the upper $2 \mathrm{~km}$ of the estuary was equivalent to roughly $25 \%$ of the daily watershed $\mathrm{N}$ loading rate and represented the bulk of the total DNF in the upper estuary. Despite the large differences in coupled denitrification rates $(0.8$ to $8.0 \mathrm{mmol} \mathrm{m} \mathrm{m}^{-2} \mathrm{~d}^{-1}$ ) between stations, the fractions of mineralized $\mathrm{N}$ that was denitrified $(44 \%$ at $13.5 \mathrm{k}$ and $6 \%$ at $14 \mathrm{k}$ ) were within the range reported for other estuaries (Hopkinson et al. 1999).

The gross $\mathrm{NO}_{3}^{-}$flux from sediments contributed significantly to the total DIN flux and the interpretation of the DIC:DIN stoichiometry. In high organic estuarine or coastal sediments where no net $\mathrm{NO}_{3}^{-}$flux from the sediments is observed, DIC: $\mathrm{NH}_{4}{ }^{+}$rather than DIC:DIN ratios have been commonly used in the stoichiometric calculation of the coupled nitrification/denitrification rate (Weston et al. 1996). Rowley River sediments clearly violated that assumption, and if the experiment had lacked the ability to detect the gross $\mathrm{NO}_{3}^{-}$flux from sediments (i.e. no ${ }^{15} \mathrm{~N}$ tracer) we would have overestimated coupled DNF by up to $20 \%$ at $13.5 \mathrm{k}$ and $220 \%$ at $14 \mathrm{k}$. However, because the gross $\mathrm{NO}_{3}^{-}$regeneration was accounted for in the direct DNF measure, total DNF rate estimates (direct + coupled) would have been unchanged if the gross $\mathrm{NO}_{3}^{-}$regeneration had not been quantified. A significant gross $\mathrm{NO}_{3}^{-}$flux from the sediments (contemporaneous with net $\mathrm{NO}_{3}^{-}$uptake) is probably not unique to the Rowley River estuary, and may be more prevalent in BMA-rich sediments. Although, benthic primary production enhances coupled DNF (An \& Joye 2001), high nitrification rates followed by large $\mathrm{NO}_{3}^{-}$fluxes from sediments may also occur when microalgal $\mathrm{O}_{2}$ production is high enough to inhibit denitrification (Tiedje 1988). Regardless, the inclusion of gross $\mathrm{NO}_{3}^{-}$regeneration into stoichiometric calculations may help explain differences between stoichiometry-based DNF estimates and those measured from direct $\mathrm{N}_{2}$ flux or isotope pairing techniques, or when stoichiometry yields DNF estimates that appear to be an unusually high percentage of total $\mathrm{N}$ mineralized (Hopkinson et al. 1999).

In summary, combining ${ }^{15} \mathrm{~N}$ isotope incorporated into benthic biota and in the overlying DIN with flux incubations demonstrated preferential recycling of benthic microalgal $\mathrm{N}$, and a 'spiraling' of $\mathrm{NO}_{3}^{-}$in the estuary through gross $\mathrm{NO}_{3}^{-}$regeneration and net $\mathrm{NO}_{3}^{-}$uptake. BMA was not a unidirectional sink for watershedderived nor porewater-derived DIN. BMA mediated rapid turnover (on the scale of days) between the water column and estuarine benthos. The gross regeneration of $\mathrm{NO}_{3}^{-}$in sediments may represent an important (but potentially unaccounted for) mechanism in BMA-rich sediments that could influence water column production and the interpretation of direct and coupled denitrification in estuaries.

Acknowledgements. We thank the following individuals who contributed to this work: Matthew Cieri, Josh Goldstein, Marshall Otter, David Vasiliou, and Nat Weston. Special appreciation is extended to J. P. Montoya for allowing DAP samples to be run in his laboratory. This work was supported by grants from the U.S. National Science Foundation (NSF-DEB 9815598, NSF-REU) and Massachusetts Sea Grant (Project R/M-141, no. NA86RG0075).

\section{LITERATURE CITED}

An S, Joye SB (2001) Enhancement of coupled nitrificationdenitrification by benthic photosynthesis in shallow estuarine sediments. Limnol Oceanogr 46:62-74

Blackburn TH, Henriksen K (1983) Nitrogen cycling in different types of sediments from Danish waters. Limnol Oceanogr 28:477-493

Boynton W, Kemp WM (1985) Nutrient regeneration and oxygen consumption by sediments along an estuarine salinity gradient. Mar Ecol Prog Ser 23:45-55

Bronk DA, Glibert PM, Ward BB (1994) Nitrogen uptake, dissolved organic nitrogen release, and new production. Science 265:1843-1845

Cabrita MT, Brotas V (2000) Seasonal variation in denitrification and dissolved nitrogen fluxes in intertidal sediments of the Tagus estuary, Portugal. Mar Ecol Prog Ser 202: $51-65$

Caffrey J (1995) Spatial and seasonal patterns in sediment nitrogen remineralization and ammonium concentrations in San Francisco Bay, California. Estuaries 18:219-233

Cerco CF, Seitzinger SP (1997) Measured and modeled effects of benthic algae on eutrophication in Indian River-Rehobeth Bay, Delaware. Estuaries 20:231-248

Cornwell JC, Kemp WM, Kana TM (1999) Denitrification in coastal ecosystems: methods, environmental controls, and ecosystem level controls, a review. Aquat Ecol 33:41-54

Diamond DH (1994) Determination of nitrate + nitrite in brackish or seawater by flow injection analysis colorimetry. QuikChem Method 31-107-04-1-C. Lachat Instruments, Loveland, CO

Dickson AG, Goyet C (eds) (1994) Handbook of methods for the analysis of the various parameters of the carbon dioxide system in sea water, version 2. ORNL/CDIAC-74, US Dept Energy, Oak Ridge, TN

Dong LF, Thornton DCO, Nedwell DB, Underwood GJC (2000) Denitrification in sediments of the River Colne estuary, England. Mar Ecol Prog Ser 203:109-122

Giblin A, Hopkinson C, Tucker J (1997) Benthic metabolism and nutrient cycling in Boston Harbor, Massachusetts. Estuaries 20:346-364

Glibert P, Capone DC (1993) Mineralization and assimilation in aquatic, sediment, and wetland systems. In: Knowles R, Blackburn TH (eds) Nitrogen isotope techniques. Academic Press, San Diego, p 243-272

Hale JM (1980) Instrumental measurements of dissolved oxygen concentrations in saline water. Technical notes. Orbisphere Laboratories, Emerson, NJ 
Herbert RA (1999) Nitrogen cycling in coastal marine ecosystems. FEMS Microbiol Rev 23:563-590

Holmes RM, McClelland JW, Sigman DM, Fry B, Peterson BJ (1997) Measuring ${ }^{15} \mathrm{NH}_{4}{ }^{+}$in marine, estuarine, and fresh waters: an adaptation of the ammonia diffusion method for samples with low ammonium concentrations. Mar Chem 60:235-243

Holmes RM, Peterson BJ, Deegan LA, Hughes JE, Fry B (2000) Nitrogen biogeochemistry in the oligohaline zone of a New England estuary. Ecology 81:416-432

Hopkinson CS, Giblin AE, Tucker J, Garritt RH (1999) Benthic metabolism and nutrient cycling along an estuarine salinity gradient. Estuaries 22:825-843

Kemp WM, Boynton WR (1984) Spatial and temporal coupling of nutrient inputs to estuarine primary production: the role of particulate transport and decomposition. Bull Mar Sci 35:522-535

Kirchman DL, Wheeler P (1998) Uptake of ammonium and nitrate by heterotrophic bacteria and phytoplankton in the sub-Arctic Pacific. Deep-Sea Res I 45:347-365

Koike I, Sorensen J (1988) Nitrate reduction and denitrification in marine sediments. In: Blackburn TH, Sorensen $\mathrm{J}$ (eds) Nitrogen cycling in coastal marine environments. John Wiley, London, p 251-270

McClelland JW, Montoya JP (2002) Trophic relationships and the nitrogen isotopic composition of amino acids in plankton. Ecology 83:2173-2180

Metges CC, Petzke K, Hennig U (1996) Gas chromatography/ combustion/isotope ratio mass spectrometric comparison of $\mathrm{N}$-acetyl- and N-pivaloyl-amino acid esters to measure ${ }^{15} \mathrm{~N}$ isotopic abundances in physiological samples: a pilot study on amino acid synthesis in the upper gastro-intestinal tract of minipigs. J Mass Spectrosc 31:367-376

Middelburg JJ, Nieuwenhuize J (2000) Nitrogen uptake by heterotrophic bacteria and phytoplankton in the nitraterich Thames estuary. Mar Ecol Prog Ser 203:13-21

Middelburg JJ, Nieuwenhuize J (2001) Nitrogen isotope tracing of dissolved inorganic nitrogen behaviour in tidal estuaries. Estuar Coast Shelf Sci 53:385-391

Middelburg JL, Barranguet C, Boschker HTS, Herman PMJ, Moens T, Heip CHR (2000) The fate of intertidal microphytobenthos carbon: an in situ ${ }^{13} \mathrm{C}$-labeling study. Limnol Oceanogr 45:1224-1234

Nielsen LP (1992) Denitrification in sediment determined from nitrogen isotope pairing. FEMS Microbiol Ecol 86:357-362

Nixon SW, Ammerman JW, Atkinson LP, Berounsky VM and 12 others (1996) The fate of nitrogen and phosphorous at the land-sea margin of the North Atlantic Ocean. Biogeochemistry 35:141-180

Pelz O, Cifuentes LA, Hammer BT, Kelley CA, Coffin RB (1998) Tracing the assimilation of organic compounds using ${ }^{13} \mathrm{C}$ analysis of unique amino acids in the bacterial peptidoglycan cell wall. FEMS Microbiol Ecol 25:229-240

Peterson BJ, Wollheim WM, Mulholland PJ, Webster JR and 11 others (2001) Control of nitrogen export from watersheds by headwater streams. Science 292:86-90

Poremba K (1994) Simulated degradation of phytodetritus in deep-sea sediments of the NE Atlantic $\left(47^{\circ} \mathrm{N}, 19^{\circ} \mathrm{W}\right)$. Mar Ecol Prog Ser 105:291-299

Risgaard-Petersen N, Rysgaard S, Nielsen LP, Revsbech NP (1994) Diurnal variation of denitrification and nitrification in sediments colonized by benthic microphytes. Limnol Oceanogr 39:573-579

Seitzinger SP (1988) Denitrification in freshwater and coastal

Editorial responsibility: Victor de Jonge (Contributing Editor), Haren, The Netherlands marine ecosystems: ecological and geochemical significance. Limnol Oceanogr 33:702-724

Seitzinger SP, Giblin AE (1996) Estimating denitrification in North Atlantic continental shelf sediments. Biogeochemistry 35:235-260

Sigman DM, Altabet MA, Michener R, McCorkle DC, Fry B, Holmes RM (1997) Natural abundance-level measurement of the nitrogen isotopic composition of oceanic nitrate: an adaptation of the ammonium diffusion method. Mar Chem $57: 227-242$

Solorzano L (1969) Determination of ammonia in natural waters by the phenolhypochlorite method. Limnol Oceanogr 14: 799-801

Sun M, Lee C, Aller RC (1993) Anoxic and oxic degradation of ${ }^{14} \mathrm{C}$-labeled chloropigments and ${ }^{14} \mathrm{C}$-labeled diatom in Long Island Sound sediments. Limnol Oceanogr 38:1438-1451

Sundbäck K, Miles A (2000) Balance between denitrification and microalgal incorporation of nitrogen in microtidal sediments, NE Kattegat. Aquat Microb Ecol 22:291-300

Sundbäck K, Miles A, Göransson E (2000) Nitrogen fluxes, denitrification and the role of microphytobenthos in microtidal shallow-water sediments: an annual study. Mar Ecol Prog Ser 200:59-76

Thornton DCO, Underwood GJC, Nedwell DB (1999) Effect of light and emersion period on the exchange of ammonium across the estuarine sediment-water interface. Mar Ecol Prog Ser 184:11-20

Tiedje JM (1988) Ecology of denitrification and dissimilatory nitrate reduction to ammonium. In: Zehnder A (ed) Biology of anaerobic organisms. John Wiley, New York, p 179-243

Tobias CR, Cieri M, Peterson BJ, Deegan LA, Vallino J, Hughes J (2003) Processing watershed-derived nitrogen in a well-flushed New England estuary. Limnol Oceanogr 48:1766-1778

Tobias CR, Anderson IC, Canuel EA, Macko SA (2001a) Nitrogen cycling through a fringing marsh-aquifer ecotone. Mar Ecol Prog Ser 210:25-39

Tobias CR, Macko SA, Anderson IC, Canuel EA, Harvey JW (2001b) Tracking the fate of a high concentration groundwater nitrate plume through a fringing marsh: a combined groundwater tracer and in situ isotope enrichment study. Limnol Oceanogr 46:1977-1989

Trimmer M, Gowen RJ, Stewart BM, Nedwell DB (1999) The spring bloom and its impact on benthic mineralisation rates in western Irish Sea sediments. Mar Ecol Prog Ser 185:37-46

Twilley RR, Cowan JJ, Miller-Way T, Montagna PA, Mortazani P (1999) Benthic nutrient fluxes in selected estuaries in the Gulf of Mexico. In: Bianchi TS, Pennock JR, Twilley RR (eds) Biogeochemistry of Gulf of Mexico estuaries. John Wiley, New York, p 163-209

Vallino JJ, Hopkinson CS (1998) Estimation of dispersion and characteristic mixing times in Plum Island Sound Estuary. Estuar Coast Shelf Sci 46:333-350

Warnken KW, Gill GA, Santschi PH, Griffin LL (2000) Benthic exchange of nutrients in Galveston Bay, Texas. Estuaries 23:647-661

Wessel WW, Tietema A (1992) Calculating gross N transformation rates of ${ }^{15} \mathrm{~N}$ pool dilution experiments with acid forest litter: analytical and numerical approaches. Soil Biol Biochem 24:931-942

Weston N, Carini S, Giblin A, Banta G, Hopkinson C, Tucker $\mathrm{J}$ (1996) Estimating denitrification in sediments of the Parker River Estuary, Massachusetts. Biol Bull (Woods Hole) 191:334-335

Submitted: July 16, 2002; Accepted: February 23, 2003

Proofs received from author(s): July 16, 2003 